\section{The Biochemical Basis for Flower Color in Calibrachoa}

\author{
Rebeccah A. Waterworth ${ }^{1}$ and Robert J. Griesbach ${ }^{2}$ \\ Floral and Nursery Plant Research, U.S. National Arboretum, U.S. Department \\ of Agriculture, Agricultural Research Service, BARC-West, BLDG. 010-A, \\ Beltsville, MD 20705-2350
}

Additional index words. Solanaceae, petunia, $\mathrm{pH}$, anthocyanins, flavonoids

\begin{abstract}
Recently, several new Calibrachoa La Llave \& Lexarza (Solanaceae Juss.) cultivars have been developed with novel red and blue flowers. Most wild species of Calibrachoa have purple flowers. The differences in color were not due to anthocyanin composition, but rather to vacuolar $\mathrm{pH}$. The $\mathrm{pH}$ of the red-flowered cultivar was 4.8 while that of the blue-flowered cultivar was 5.6. The wild purple-flowered species had an intermediate $\mathrm{pH}$ of 5.0. These data suggest that different $\mathrm{pH}$ and pigment genes may be introgressed into other Calibrachoa species to increase cultivar diversity.
\end{abstract}

Calibrachoa La Llave \& Lexarza (Solanaceae Juss.) is becoming an important new landscape plant, the first cultivars having been released in the early 1990s (Poehlman, 1997). This genus is very closely related to the wellknown genus Petunia Jussieu. Historically, Calibrachoa species were included in Petunia because of their morphological similarity. Wijsman and Jong (1985) first recognized that there were two distinct groups of species based upon chromosome number. Therefore, they transferred 15 Petunia species into the genus Calibrachoa (Wijsman, 1990). Recently, an additional seven species have been added (Stehman and Semir, 1997). Calibrachoa species are characterized by a $2 \mathrm{n}=18$ chromosome number, woody stems, conduplicate aestivation with two petals covering the other three, and seedcoat cells with straight anticlinal walls. Petunia species are characterized by a $2 n=14$ chromosome number, nonwoody stems, imbricate aestivation, and seedcoat cells with wavy anticlinal walls (Stehman and Semir, 1997).

Most wild species of Calibrachoa have purple flowers. Recently, several new cultivars have been developed with novel flower colors. The objective of this study was to determine the biochemical basis of these novel blue and red flower colors.

\section{Materials and Methods}

Plant material. Plants of hybrid Calibrachoa 'Million Bells Trailing Blue' and 'Million Bells Cherry' (Suntory, Tokyo) were obtained from a local retail nursery. Plants of the wild species C. sellowiana 'Rose' (Sendtr.)

\footnotetext{
Received for publication. 10 Jan. 2000 Accepted for publication. 17 May 2000. The cost of publishing this paper was defrayed in part by the payment of page charges. Under postal regulations, this paper therefore must be hereby marked advertisement solely to indicate this fact.

${ }^{1}$ Student Intern.

${ }^{2}$ Research Geneticist. To whom requests for reprints
} should be addressed.
Wijsman were obtained from K.C. Sink, Michigan State Univ., under the name $P$. alpicola Smith \& Downs. A seedling population was created from the cross of 'Million Bells Trailing Blue' and 'Million Bells Cherry'. All plants were maintained in a greenhouse under standard cultural practices for Petunia (Dole and Wilkins, 1999). The daylength was $16 \mathrm{~h}$ at $25{ }^{\circ} \mathrm{C}$ day $/ 20{ }^{\circ} \mathrm{C}$ night. Supplemental HID lighting with incandescent light was used to extend the daylength. The maximum light intensity was $1050 \mu \mathrm{mol} \cdot \mathrm{m}^{-2} \cdot \mathrm{s}^{-1}$. The Royal Horticultural Society (RHS) Colour Charts (RHS, 1986) were used to denote flower color using only the first chip as suggested by Voss and Hale (1998).

Flavonoid analysis. Anthocyanins and flavonols were isolated and analyzed by high resolution, high performance liquid chromatography (HPLC) as described by Griesbach et al. (1991). Individual anthocyanins were purified by preparatory HLPC and then hydrolyzed (Griesbach et al., 1991). The hydrolyzation products were characterized by diagnostic visible and ultraviolet spectrophotometry and by thin layer chromatography (TLC) with known standards. Individual anthocyanins are reported as the percentage of total anthocyanin present. Each value is the mean of three singleflower replicates from the same plant harvested on different days. The Student's $t$ test was used to compare the means.
${ }^{\mathrm{y}}$ Mean (standard deviation)
pH Determination. The $\mathrm{pH}$ of petal cell sap was determined 1 day after anthesis. Griesbach (1998) reported that the $\mathrm{pH}$ of the whole petal tissue was the same as the $\mathrm{pH}$ of just the upper epidermis. Therefore, the whole tissue was homogenized and the $\mathrm{pH}$ measured with a Sentron $1001 \mathrm{pH}$ meter (Sentron, Federal Way, Wash.). The $\mathrm{pH}$ measurements are reported as the mean of 10 replicates with each replicate representing a different flower. The Student's $t$ test was used to compare the means.

Anthocyanin-flavonol complex. An anthocyanin-flavonol complex was created as previously described by Asen et. al. (1986). The absorption of this complex was measured at $\mathrm{pH} 5.6$ and 4.8, which were based upon the $\mathrm{pH}$ of the cultivars.

\section{Results and Discussion}

The HPLC profiles of the flavonols were the same for 'Rose', 'Million Bells Trailing Blue' and 'Million Bells Cherry' (data not shown). Upon hydrolysis, a single flavonol (kaempferol) was identified. Based upon the anthocyanin and flavonol composition of the cultivars, the anthocyanin to flavonol ratio was $1: 1.7$.

Both malvidin and petunidin were found in 'Rose', 'Million Bells Cherry' and 'Million Bells Trailing Blue' (Table 1). 'Million Bells Cherry' had a higher concentration $(t=30.575$, $P \leq 0.001)$ of petunidin than malvidin, whereas the reverse was true for 'Rose' and 'Million Bells Trailing Blue'. Four anthocyanins were detected in these cultivars-petunidin-3caffeoylrutinoside-5-glucoside (Pt-ca), petunidin-3-coumarylrutinoside-5-glucoside (Pt-co), malvidin-3-caffeoylrutinoside-5-glucoside (Mv-ca), and malvidin-3-coumarylrutinoside-5-glucoside (Mv-co). In 'Million Bells Trailing Blue' and 'Rose', Mv-ca was the major anthocyanin and comprised nearly $70 \%$ of the total anthocyanin content. However, three anthocyanins were present in about equal concentrations in 'Million Bells Cherry'.

These results might lead one to conclude that the anthocyanin composition was responsible for the differences in flower color among 'Rose' (RHS 81A), 'Million Bells Trailing Blue' (RHS 88A), and 'Million Bells Cherry' (RHS 67A). However, this is incorrect (the differences in anthocyanin composition cannot explain the variation in flower color), because the acylated 3-rutinoside-5-glucosides

Table 1. The color, petal $\mathrm{pH}$, and anthocyanin composition of Calibrachoa sellowiana 'Rose' (Rose) and $C$. hybrids 'Million Bells Trailing Blue' (Blue), 'Million Bells Cherry' (Cherry), and the hybrid between 'Million Bells Trailing Blue' and 'Million Bells Cherry' (Hybrid). Abbreviations $\mathrm{Pt}$-ca $=$ petunidin-3-caffeoylrutinoside-5-glucoside; $\mathrm{Pt}$-co $=$ petunidin-3coumarylrutinoside-5-glucoside; $\mathrm{Mv}$-ca = malvidin-3-caffeoylrutinoside5-glucoside; and Mv-co = malvidin-3-coumarylrutinoside-5-glucoside.

\begin{tabular}{lccrrrr}
\hline \hline Plant & Color $^{\mathrm{z}}$ & $\mathrm{pH}$ & \multicolumn{1}{c}{ Pt-ca } & Pt-co & Mv-ca & Mv-co \\
\hline Rose & $81 \mathrm{~A}$ & $5.0(0.1)^{\mathrm{y}}$ & $8(2)$ & $9(1)$ & $67(9)$ & $16(5)$ \\
Blue & 88A & $5.6(0.3)$ & $8(2)$ & $20(1)$ & $68(1)$ & $7(2)$ \\
Cherry & $67 \mathrm{~A}$ & $4.8(0.1)$ & $34(1)$ & $30(1)$ & $24(1)$ & $12(1)$ \\
Hybrid & $74 \mathrm{~A}$ & $5.3(0.2)$ & $14(2)$ & $31(1)$ & $23(1)$ & $32(1)$ \\
\hline
\end{tabular}

${ }^{\text {2RHS Colour Chart (Royal Horticultural Society, 1986) }}$ 
